\title{
The Development and Application of Wooden Materials in Turkish Arts ${ }^{\dagger}$
}

\author{
Aytaç Akinay 1,** \\ 1 Van Vocational School, Department of Material and Material Processing Technologies, Furniture And Decoration \\ Program \\ * Correspondence: aytacakinay@yyu.edu.tr; \\ $\dagger$ Presented at Materials Chemistry and Physics (Materials Chemistry 2020) - International e-Conference
}

Received: 16.09.2020; Revised: 20.09.2020; Accepted: 24.09.2020; Published: 27.09.2020

\begin{abstract}
Wood is a kind of material that humanity has used continuously since the day it existed. Wood materials that have been used in many areas of life in the historical process has also been preferred in handicrafts. Moreover, these materials have been used continuously in Turkish Handicrafts from past to present. Especially the Anatolian Seljuks showed original examples of wood materials art in works such as pulpit, mihrab, sarcophagus, lectern, door, and window wings. Kündekari and wood carving technique, which is a kind of interlacing technique in decoration, has been applied in walnut, ebony, rose, and oak wood materials. On the other hand, different surface coating processes such as painting and polishing were applied to these materials for decoration. Wood art continued to increase with wood carving techniques such as inlay, openwork bonding, tarsi, and Edirnekari in the Ottoman. There has been an increase in the variety of wood materials used with the increasing techniques. Hence, original wood samples were given in Ottoman wood art with a variety of materials and rich decoration techniques.
\end{abstract}

Keywords: wood materials; surface processing; Turkish handicrafts; surface coating.

(C) 2020 by the authors. This article is an open-access article distributed under the terms and conditions of the Creative Commons Attribution (CC BY) license (https://creativecommons.org/licenses/by/4.0/).

\section{Funding}

This research received no external funding.

\section{Acknowledgments}

This research has no acknowledgment.

\section{Conflicts of Interest}

The authors declare no conflict of interest. 